\title{
HUBUNGAN ANTARA KECENDERUNGAN KEPRIBADIAN NEUROTISME DENGAN PERILAKU MEROKOK
}

\author{
Tyas Martika Anggriana*
}

\begin{abstract}
Abstrak
Perilaku merokok adalah sesuatu yang dilakukan seseorang, berupa membakar rokok dan menghisapnya serta dapat menimbulkan asap yang dapat terhisap oleh orang-orang disekitarnya. Meskipun berbahaya bagi kesehatan, pada kenyataannya perilaku merokok tetap meningkat secara kuantitas. Menurut Conrad dan Miller (dalam Sitepoe, 2000:17), dorongan psikologis menyebabkan seseorang berperilaku merokok dengan alasan untuk mengalihkan kecemasan yang dialaminya.

Penelitian ini menggunakan pendekatan kuantitatif-non eksperimental. Pengujian daya beda aitem alat ukur menggunakan uji Product Moment, sedangkan estimasi reliabilitasnya menggunakan koefisien reliabilitas Alpha. Penelitian ini mengambil sample dari sebagian mahasiswa laki-laki pada Program Studi Bimbingan dan Konseling IKIP PGRI Madiun dengan jumlah sample 132 mahasiswa dengan menggunakan teknik incidental sampling.

Berdasarkan uji hipotesis diperoleh hasil tidak ada hubungan yang signifikan antara perilaku merokok dengan kecenderungan kepribadian neurotisme, artinya tingginya kecenderungan kepribadian neurotisme tidak berhubungan dengan tingginya perilaku merokok. Demikian pula sebaliknya, rendahnya kecenderungan kepribadian neurotisme tidak berhubungan dengan rendahnya perilaku merokok. Tidak adanya hubungan antara perilaku merokok dengan kecenderungan kepribadian neurotisme pada kemungkinan disebabkan karena ada faktor-faktor lain selain kepribadian neurotisme yang juga mempengaruhi mahasiswa Program Studi Bimbingan dan Konseling untuk memiliki perilaku merokok. Faktor-faktor tersebut menurut Smet (1994:294-295), antara lain: lingkungan sosial, seperti teman sebaya, orangtua, saudara dan media.
\end{abstract}

Kata Kunci: Kepribadian Neurotisme, Perilaku Merokok

* Tyas Martika Anggriana adalah Dosen Bimbingan dan Konseling IKIP PGRI Madiun 


\section{Pendahuluan}

Tradisi merokok yang memanfaatkan tembakau mulai berkembang dari Eropa. Di Indonesia pabrik rokok mulai tumbuh pada tahun 1925 (Sitepoe, 2000:1). Seiring dengan perkembangan zaman, masyarakat luas tertarik untuk mengonsumsi rokok dengan berbagai pilihan, sehingga konsumsi rokok pun semakin bertambah dari tahun ke tahun.

Perilaku merokok adalah sesuatu yang dilakukan seseorang, berupa membakar rokok dan menghisapnya serta dapat menimbulkan asap yang dapat terhisap oleh orang-orang disekitarnya (Levy dkk, 1984:33). Aritonang (dalam Sari dkk, 2001:1) menulis bahwa merokok adalah perilaku yang kompleks, karena merupakan hasil interaksi dari aspek kognitif, lingkungan sosial, kondisi psikologis, conditioning (pengkondisian atau pembiasaan), dan keadaan psikologis. Secara kognitif, para perokok tidak memperlihatkan keyakinan yang tinggi terhadap bahaya yang didapat dari merokok. Bila ditinjau dari aspek sosial, sebagian besar perokok menyatakan bahwa mereka merokok karena terpengaruh oleh orang-orang lain disekitarnya. Secara psikologis, perilaku merokok dilakukan untuk relaksasi, mengurangi ketegangan dan melupakan sejenak masalah yang sedang dihadapi.

Perilaku merokok individu dapat digambarkan menurut tiga dimensi, yaitu frekuensi, lamanya berlangsung dan intensitas (Twiford dan Soekaji dikutip Sibuea, 2000:10). Meskipun berbahaya bagi kesehatan, pada kenyataannya perilaku merokok tetap meningkat. Ada berbagai macam alasan seseorang berperilaku merokok, antara lain menurut Smet (1994:294), perilaku merokok seseorang dipengaruhi oleh faktor lingkungan sosial seperti teman sebaya dan saudara; faktor demografis yaitu umur dan jenis kelamin; dan faktor sosiokultural seperti kebiasaan dan kebudayaan, kelas sosial, tingkat pendidikan, taraf penghasilan, maupun gengsi pekerjaan. Seluruh faktor di atas, merupakan faktorfaktor eksternal.

Faktor-faktor internal yang dapat mempengaruhi perilaku merokok seseorang adalah faktor psikologis, psikososial, dan kepribadian. Menurut Conrad dan Miller (Sitepoe, 2000:17), dorongan psikologis menyebabkan seseorang 
berperilaku merokok dengan alasan untuk mengalihkan kecemasan yang dialaminya.

Faktor psikologi juga erat kaitannya dengan faktor kepribadian. Menurut Atkinson (1991:294), selain faktor orang tua dan teman, faktor kepribadian juga dapat mempengaruhi perilaku merokok seseorang, seperti karena adanya rasa ingin tahu atau untuk melepaskan diri dari rasa bosan. Fiske (dalam Widyorini, 2002:30) mengemukakan bahwa struktur kepribadian terdiri dari lima besar faktor, yaitu neurotisme, ekstraversi, keterbukaan, kecocokan dan keberhatihatian.

Neurotisme merupakan salah satu dari lima besar faktor kepribadian (the big five factors model) yang menggambarkan perbedaan antara penyesuaian atau stabilitas emosional dengan ketidakmampuan penyesuaian diri. Seseorang dengan kepribadian neurotisme cenderung mudah mengalami emosi-emosi negatif atau tidak stabil seperti cemas, takut, mudah marah, depresi, dan tidak nyaman yang berakibat maladjustment (ketidakmampuan menyesuaikan diri). Untuk mengatasi ketegangan atau emosi-emosi negatif tersebut, seseorang memilih berperilaku merokok, agar mendapatkan ketenangan, perasaan menyenangkan dan kepuasan. Hal ini sesuai dengan temuan Horn dkk (Parrott, 1999) bahwa 80\% perokok setuju dengan pernyataan yang menyatakan bahwa merokok sangat menenangkan dan menyenangkan. Oleh karena mendapatkan kepuasan, seseorang akan terus mengulangi perbuatannya, yaitu merokok setiap kali cemas atau depresi.

Perokok ternyata tidak hanya terdiri dari kalangan-kalangan tertentu saja, tetapi juga dari seluruh lapisan masyarakat dan berbagai bidang profesi termasuk mahasiswa. Demikian halnya dengan mahasiswa di Program Studi Bimbingan dan Konseling IKIP PGRI Madiun yang berjenis kelamin laki-laki. Mahasiswa Program Studi Bimbingan dan Konseling tidak berbeda dengan orang lain pada umumnya yang juga memiliki peluang yang sama untuk dapat mudah mengalami keadaan emosional yang tidak stabil berupa emosi-emosi negatif seperti kecemasan, stres dan depresi. Ini disebabkan karena beban penguasaan ilmu yang dipelajari, banyaknya tugas yang diberikan, ataupun kondisi-kondisi lain yang disebabkan oleh konflik atau ketegangan sehingga menimbulkan stres baik di rumah, di kos-kosan ataupun di lingkungan pendidikan. Oleh karena itu tidak 
menutup kemungkinan pula bagi mahasiswa Program Studi Bimbingan dan Konseling yang berusaha mengatasi emosi-emosi negatif, seperti kecemasan, stres dan depresi dengan berperilaku merokok agar timbul perasaan senang dan menenangkan.

Berdasarkan uraian permasalahan di atas, maka rumusan masalah dalam penelitian ini adalah adakah hubungan antara kecenderungan kepribadian neurotisme dengan perilaku merokok pada mahasiswa Program Studi Bimbingan dan Konseling IKIP PGRI Madiun? Artinya, semakin tinggi kecenderungan kepribadian neurotisme yang dimiliki seseorang, maka semakin tinggi perilaku merokok seseorang, dan sebaliknya, semakin rendah kecenderungan kepribadian neurotisme yang dimiliki seseorang, maka semakin rendah perilaku merokoknya. Penelitian ini diharapkan dapat memberikan manfaat bagi pengembangan ilmu Psikologi tentang perilaku merokok kaitannya dengan kecenderungan kepribadian neurotisme.

\section{Metode Penelitian}

Penelitian ini menggunakan pendekatan kuantitatif-non eksperimental. Penelitian ini akan meneliti hubungan sebab-akibat yang tidak dimanipulasi atau diberi perlakuan, sehingga penelitian ini termasuk penelitian expost-facto (Sukmadinata, 2009:55).

Penelitian ini menggunakan dua macam variabel, yaitu variabel bebas (X) dan variabel terikat (Y). Variabel bebas dalam penelitian ini adalah kecenderungan kepribadian neurotisme, sedangkan variabel terikatnya adalah perilaku merokok. Kecenderungan kepribadian neurotisme merupakan faktor internal yang diprediksi mempengaruhi perilaku merokok.

Penelitian dilakukan pada bulan Januari - Februari 2011 pada Program Studi Bimbingan dan Konseling IKIP PGRI Madiun. Populasi dalam penelitian ini adalah mahasiswa laki-laki di Program Studi Bimbingan dan Konseling IKIP PGRI Madiun yang berjumlah 203 mahasiswa. Sampel yang diambil dalam penelitian ini sebanyak 132 mahasiswa. Perhitungan jumlah sample didasarkan atas tabel Krejcie-Morgan. Pengambilan sampel dalam penelitian ini menggunakan teknik inciental sampling, yaitu teknik pengambilan sampel secara 
kebetulan atau yang dijadikan subyek penelitian adalah subyek yang dijumpai secara kebetulan (Hadi, 2004:184).

Metode pengumpulan data dalam penelitian ini menggunakan dua macam instrumen, yaitu angket perilaku merokok dan skala kecenderungan kepribadian neurotisme. Angket perilaku merokok disusun berdasarkan aspek-aspek perilaku merokok dari Twiford (1998:11-15 dikutip Sibuea, 2000:10): frekuensi (mengetahui sejauhmana perilaku merokok seseorang sering muncul atau tidak); lamanya berlangsung (waktu yang diperlukan seseorang untuk melakukan setiap tindakan (seseorang menghisap rokok lama atau tidak); dan intensitas (mengukur seberapa dalam dan seberapa banyak seseorang menghisap rokok).

Skala kecenderungan kepribadian neurotisme disusun berdasarkan enam aspek kecenderungan kepribadian neurotisme, yaitu Kecemasan, Rasa Permusuhan dan Kemarahan, Depresi, Kesadaran Diri, Impulsivitas dan Kerentanan.

Sebelum melakukan penelitian, terlebih dahulu dilakukan uji coba alat ukur untuk mengetahui apakah alat ukur mampu menghasilkan data yang akurat sesuai dengan tujuan penelitian. Data uji coba dilakukan untuk menghitung daya beda aitem dan estimasi reliabilitas alat ukur. Uji daya beda aitem alat ukur dilakukan dengan menggunakan teknik korelasi Product Moment, sedangkan estimasi reliabilitasnya menggunakan teknik koefisien Alpha Cronbach.

Hasil uji daya beda dan reliabilitas yang dilakukan terhadap 45 aitem angket perilaku merokok, terdapat 45 aitem yang memiliki konsistensi internal. Perhitungannya dilakukan secara terpisah berdasarkan golongan jenis rokoknya yaitu, 15 aitem untuk golongan rokok jenis mild dengan menggunakan korelasi aitem total 0,3 dan taraf signifikansi 5\%. Berdasarkan 15 aitem yang memiliki konsistensi internal diperoleh koefisien korelasi aitem total terkoreksi bergerak antara 0,459-0,860. Hasil analisis reliabilitas menghasilkan koefisien Alpha sebesar 0,937. Kemudian 15 aitem untuk golongan rokok jenis filter dengan menggunakan korelasi aitem total 0,3 dan taraf signifikansi 5\%. Berdasarkan 15 aitem yang memiliki konsistensi internal diperoleh koefisien korelasi aitem total terkoreksi bergerak antara 0,746-0,945. Hasil analisis reliabilitas menghasilkan koefisien Alpha sebesar 0,966. Sedangkan 15 aitem untuk golongan rokok jenis 
kretek dengan menggunakan korelasi aitem total 0,3 dan taraf signifikansi 5\%. Berdasarkan 15 aitem yang memiliki konsistensi internal diperoleh koefisien korelasi aitem total terkoreksi bergerak antara 0,768-0,973. Hasil analisis reliabilitas menghasilkan kefisien Alpha sebesar 0,976.

Hasil uji daya beda dan reliabilitas yang dilakukan terhadap 60 aitem skala kecenderungan kepribadian neurotisme, terdapat 34 aitem yang memiliki konsistensi internal dan 26 aitem gugur dengan menggunakan korelasi aitem total 0,3 dan taraf signifikansi $5 \%$.

Data penelitian yang terkumpul dari lapangan selanjutnya dianalisis dengan menggunakan teknik korelasi product moment untuk mengetahui ada tidaknya hubungan antar variabel yang diteliti. Data yang diperoleh dari alat ukur penelitian terlebih dahulu dilakukan uji asumsi yang meliputi uji normalitas dan uji linearitas.

\section{Hasil Penelitian}

Berdasarkan hasil pengumpulan data diperoleh data-data tentang kategori subjek penelitian. Distribusi normal kelompok subyek dalam penelitian ini dibagi atas lima bagian atau lima satuan deviasi standar, sehingga diperoleh $6 / 5=1,2$. Adapun norma kategorisasi yang digunakan adalah sebagai berikut: kategori "sangat tinggi" $(\mu+1,8 \sigma<\mathrm{x} \leq \mu+3 \sigma)$; kategori "tinggi" $(\mu+0,6 \sigma<\mathrm{x} \leq \mu+$

$1,8 \sigma)$; kategori "sedang" $(\mu-0,6 \sigma<\mathrm{x} \leq \mu+0,6 \sigma)$; kategori "rendah" $(\mu-1,8 \sigma<$ $\mathrm{x} \leq \mu-0,6 \sigma)$; dan kategori "sangat rendah" $(\mu-3 \sigma<\mathrm{x} \leq \mu-1,8 \sigma)$.

Berikut adalah deskripsi data dari masing-masing skala, antara lain:

1. Deskripsi data angket perilaku merokok.

Berdasarkan norma kategorisasi dengan distribusi normal kelompok subyek dalam penelitian ini, rentang skor subyek pada angket perilaku merokok berada dalam kategori rendah yaitu 108,63 (berdasarkan mean empirik).

2. Deskripasi data skala kecenderungan kepribadian neurotisme

Berdasarkan norma kategorisasi dengan distribusi normal kelompok subyek dalam penelitian ini, rentang skor subyek pada skala kecenderungan 
kepribadian neurotisme berada dalam kategori sedang yaitu 82,87 (berdasarkan mean empirik).

Pengujian untuk mengetahui ada tidaknya hubungan antara perilaku merokok dengan kecenderungan kepribadian neurotisme menggunakan teknik korelasi Product Moment. Hasil analisis menunjukkan bahwa koefisien korelasi antara perilaku merokok dengan kecenderungan kepribadian neurotisme sebesar $\mathrm{r}_{\mathrm{xy}}=0,101$ dengan signifikansi $0,403(\mathrm{p}>0,05)$. Hasil tersebut menunjukkan bahwa tidak ada hubungan yang signifikan antara perilaku merokok dengan kecenderungan kepribadian neurotisme, artinya tingginya kecenderungan kepribadian neurotisme tidak berhubungan dengan tingginya perilaku merokok. Demikian pula sebaliknya, rendahnya kecenderungan kepribadian neurotisme tidak berhubungan dengan rendahnya perilaku merokok.

\section{Pembahasan}

Berdasarkan hasil penelitian yang telah dilakukan menunjukkan bahwa tidak ada hubungan yang signifikan antara perilaku merokok dengan kecenderungan kepribadian neurotisme pada mahasiswa Program Studi Bimbingan dan Konseling IKIP PGRI Madiun. Hasil uji korelasi antara perilaku merokok dengan kecenderungan kepribadian neurotisme yang diperoleh dengan menggunakan taknik korelasi Product Moment menunjukkan nilai $\mathrm{r}_{\mathrm{xy}}$ sebesar 0,101 dengan $\mathrm{p}=0,403(\mathrm{p}>0,05)$, sehingga semakin tinggi kecenderungan kepribadian neurotisme tidak diikuti dengan semakin tinggi pula perilaku merokoknya, dan sebaliknya, semakin rendah kecenderungan kepribadian neurotisme tidak diikuti dengan perilaku merokok yang rendah pula pada mahasiswa Program Studi Bimbingan dan Konseling IKIP PGRI Madiun.

Tidak adanya hubungan antara perilaku merokok dengan kecenderungan kepribadian neurotisme pada kemungkinan disebabkan karena ada faktor-faktor lain selain kepribadian neurotisme yang juga mempengaruhi mahasiswa Program Studi Bimbingan dan Konseling untuk memiliki perilaku merokok. Faktor-faktor tersebut menurut Smet (1994:294), antara lain lingkungan sosial, seperti teman sebaya, orangtua, saudara dan media. 
Faktor lingkungan sosial sangat berpengaruh terhadap sikap, kepercayaan, dan perhatian individu terhadap rokok. Lingkungan yang menerima perilaku merokok akan menyebabkan seseorang untuk mempertahankan perilaku merokoknya. Demikian pula sebaliknya, lingkungan yang tidak menerima perilaku merokok akan membentuk persepsi sebaliknya, lingkungan yang tidak menerima perilaku merokok akan membentuk persepsi bersama tentang sisi negatif merokok dan akan mempengaruhi orang yang merokok untuk mengubah pandangannya tentang rokok; demografis, yaitu umur dan jenis kelamin. Semakin muda usia seseorang mulai merokok, semakin besar kemungkinan untuk merokok di kemudian hari; sosialkutural, yaitu meliputi kebiasaan dan kebudayaan, kelas sosial, tingkat pendidikan, taraf penghasilan dan gengsi pekerjaan. Masyarakat menengah pada umumnya menghisap satu bungkus rokok setiap hari yang terdiri dari dua puuh batang. Sedangkan orang-orang pedagang atau orang bisnis dapat menghisap rokok antara satu setengah sampai tiga bungkus rokok (Nainggolan, 1996:33).

Selain faktor-faktor diatas, ada faktor lain yang juga mempengaruhi perilaku merokok, yaitu faktor psikologis. Menurut Danusantoso (1991:6-8) merokok dapat bermakna untuk meningkatan konsentrasi, menghalau rasa mengantuk, mengakrabkan suasana sehingga timbul rasa persaudaraan, juga dapat memberi kesan modern dan berwibawa.

Kondisi kecenderungan kepribadian neurotisme mahasiswa Program Studi Bimbingan dan Konseling IKIP PGRI Madiun tergolong dalam kategori sedang. Hal ini menunjukkan bahwa mahasiswa Program Studi Bimbingan dan Konseling IKIP PGRI Madiun masih mampu mengatasi dan meningkatkan kekebalan terhadap kecemasan, stres dan depresi ataupun emosi-emosi negatif lainnya. Kondisi perilaku merokok secara keseluruhan mahasiswa Program Studi Bimbingan dan Konseling IKIP PGRI Madiun tergolong dalam kategori rendah.

Hal inilah yang memungkinkan hubungan antara variabel tergantung (perilaku merokok) dengan variabel bebas (kecenderungan kepribadian neurotisme) tidak terdapat korelasi yang signifikan, sehingga hipotesis yang diajukan ditolak artinya tidak ada hubungan positif antara perilaku merokok 
dengan kecenderungan kepribadian neurotisme pada mahasiswa Program Studi Bimbingan dan Konseling IKIP PGRI Madiun.

\section{Kesimpulan dan Saran}

Kesimpulan yang dapat diambil berdasarkan hasil penelitian dan pengujian hipotesis adalah bahwa tidak ada hubungan positif yang signifikan antara kecenderungan kepribadian neurotisme dengan perilaku merokok, yang artinya semakin tinggi kecenderungan kepribadian neurotisme seseorang tidak berpengaruh terhadap tingginya perilaku merokok seseorang. Demikian pula sebaliknya, semakin rendah kecenderungan kepribadian neurotisme seseorang tidak berpengaruh terhadap rendahnya perilaku merokok seseorang. Ada hal lain selain kepribadian neurotisme yang juga mempengaruhi perilaku merokok mahasiswa Program Studi Bimbingan dan Konseling IKIP PGRI Madiun, seperti lingkungan sosial (teman, orangtua, saudara, media), demografis, sosialkultural (kebiasaan atau kebudayaan, kelas sosial, tingkat pendidikan, kekayaan), psikologis, kognitif, biologis, dan psikososial, dan faktor-faktor lainnya.

Berdasarkan hasil penelitian yang telah dilakukan, ada beberapa saran yang dapat diberikan kepada pihak-pihak terkait, antara lain:

1. Bagi mahasiswa Program Studi Bimbingan dan Konseling IKIP PGRI Madiun Bagi mahasiswa Program Studi Bimbingan dan Konseling IKIP PGRI Madiun yang memiliki perilaku merokok rendah diharapkan dapat mempertahankan perilaku merokoknya agar tetap rendah atau bahkan menguranginya.

2. Bagi peneliti lain

Bagi peneliti selanjutnya yang berminta untuk mengetahui lebih lanjut tentang perilaku merokok, disarankan untuk melibatkan faktor-faktor lain yang dipandang berpengaruh tetapi belum disertakan dalam penelitian ini seperti faktor eksternal, yaitu faktor lingkungan sosial, faktor demografis, faktor sosialkultural, dan faktor internal, yaitu faktor psikologis, faktor biologis, faktor kognitif, dan faktor psikososial, dan faktor-faktor lainnya. Serta lebih meningkatkan metode penelitian yang digunakan agar dapat mengatasi kelemahan-kelemahan penelitian. 


\section{Daftar Pustaka}

Atkinson, R. L. 1991. Pengantar Psikologi Jilid 2. Alih Bahasa: Budi Susetyo. Jakarta: Erlangga

Danusantoso, H. 1991. Rokok dan Perokok. Jakarta: Arcan

Hadi, S. 2001. Metodologi Research. Jilid 1. Yogyakarta: Andi Offset

Kristanti, Ch., M. Suhardi, Sapardiyah, S., 1998. Perilaku Merokok dan Minum Alkohol pada Remaja di Propinsi Jawa Barat dan Bali 1995. Jurnal Epidemiologi Indonesia. Vol. 2 Edisi 3. Badan Penelitian dan Pengembangan Kesehatan. Departemen Kesehatan RI

Levy, M. R., Dignan, M. \& Shirrefs, J. A., 1984. Life and Health. New York: Random House

Nainggolan, R. A. 1996. Anda Mau Berhenti Merokok? Pasti Berhasil! Bandung: Indonesia Publishing House

Novitawati, M., Rahayu S., \& Lasmono, H. K. 2001. Pengaruh Rational Bibliotherapy Terhadap Penurunan Perilaku Merokok dengan The Transtheoritical Model of Behavior Change Sebagai Acuan Pengukuran. Indonesian Psychological Journal. Vol. 16 No. 3. Surabaya: Fakultas Psikologi Universitas Airlangga

Parrot, C. A. 1999. Does Cigarette Smoking Cause Stress?. American Psychological Association. October, Vol. 54, No. 10, h. 817-820

Sari, A. T. O., Ramdhani, N., \& Eliza M. 2001. Empati dan Perilaku Merokok di Tempat Umum. Jurnal Psikologi Indonesia. Vol. 26. No. 1. Yogyakarta: Fakultas Psikologi Universitas Gadjah Mada

Sitepoe, M. 2000. Kekhususan Rokok Indonesia. Jakarta: PT. Grasindo Smet, B. 1994. Psikologi Kesehatan. Jakarta: Gramedia Bina Widyaisawara Widyorini, E. 2002. Personality Characteristics and Social Competence of Indonesian Gifted and Non-Gifted Adolescents. Dissertation. Netherlands: University of Nijmegen 